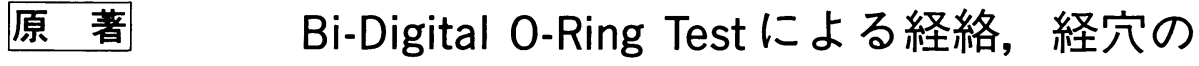 イメージングについて
}

第 6 報 脳の各部位別イメージングについて—

重 松 俊朗*田山文隆

要旨 神経伝達物質を使用するO.R.T法を用いて主な脳の各組織を使 用しイメージングを行う。

前頭葉(ブロードマン大脳皮質11野)は㐫会穴付近より始まり，斜後 外方に走行し, 膀胱(ガバ)経と平行に走行し, 上天柱穴付近に終る。 頭頂葉(ブロードマン大脳皮質 4 野) は前頂穴付近より始まり, 斜後 外方に走行し, 前頭葉(経)の内側を走行し, 上天柱穴付近に終る。

中心灰白質は百会穴を示す。中心灰白質は百会穴より斜前外方へ走 行し, 承光穴(症例により通天穴)付近で膀胱 (ガバ)経を横切り, 斜後 外方へ走行し膀胱(セロトニン)経を横切って全身へ走行する。

中脳(赤核を含む線で切除した組織)は強問穴付近より始まり斜後外 方へ走行し, 膀胱経を横切って風地究付近に終る。

後頭葉(ブロードマン大脳皮質17野)は強問穴と脳戸穴の中間付近よ

り始まり斜後外方へ走行し膀胱経を横切って風地穴付近に終る。

橋(青斑核を含む線で切除した組織)に脳戸穴付近より始まり後頭葉 と同じように風地穴付近に終る。

延髄(延髄膨大部で下オリーブ核を含む線で切除した組織)は外後頭 隆起のすぐ下より始まり, 後頭葉と同じように風地穴付近に終る。

この経穴は上半分が延髄に反応し, 下半分が海馬に反応する。

側頭葉 (ブロードマン大脳皮質21野)は懸顱穴付近より始まり側頭部 を走行し, 完骨穴付近で終る症例や膀胱(セロトニン)に合する症例も ある。

小脳(歯状核を含む線で切除した組織)な督脈上の第 2 頸椎の高さよ り始まり第 4 頸椎の高さで終る。

このことより中枢神経に関する疾患の治療に頭頸部の督脈上の経穴, 上天柱穴, 天柱穴, 風地穴は有効な経穴であると示唆された。

* Shunro SHIGEMATSU 東洋医学筑後研究会 共同研究者：Fumitaka TAYAMA 東洋医学筑後研究会 Key Words : 大脳皮質, 神経伝達物質, O.R.T法

\section{I は じめに}

頭針療法は頭皮内に針刺激することにより，目 的とする脳に刺激をあたえて治療する方法である。 このことをたしかめるためにO.R.T.法で検索した ところ脳の各部位別に興味ある所見を得たので報 
告する。

\section{II 実験方法}

対象は健康男子 4 名( 17 42歳)平均 24 歳, 女性 2 名(22 28歳), 平均 25 歳の計 6 名である。

実験方法は第 1 報, ${ }^{1)}$, 第 2 報 ${ }^{2)}$, 第 3 報 ${ }^{3)}$ で報告 したとおりに施行する。

\section{III 実験 材 料}

前頭葉 ブロードマン大脳皮質11野 頭頂葉 ブロードマン大脳皮質 4 野 中心灰白質

中脳，赤核を含む線で切除した組織 後頭葉 ブロードマン大脳皮質 17 野 橋 青斑核を含む線で切除した組織

延髄延髄膨大部で下オリーブ核を含む線で切 除した組織

側頭葉 ブロードマン大脳皮質 21 野 小脳歯状核を含む線で切除した組織 ブロードマン大脳皮質10野，9野，8野，6野， 7 野, 19 野

\section{IV 実験 成 績}

中心灰白質を百会穴を示す，百会穴は外周円の 前方が下垂体 (アドレナリン), 後方が下垂体(ガバ) に反応し, 内周円が中心灰白質に反応し, 内部の 前半分が黒質に反応し, 後半分が肝蔵(肝経)に反 応する。中心死白質は百会穴より斜前外方へ走行 し承光穴(症例により通天穴)付近で膀胱(ガバ)経 を横切り，斜後方へ走行し膀胱(セロトニン)経を 横切って全身へ走行する(図 1 )。

前頭葉(神経伝達物質アセチルコリン)は自会穴 付近より始まり, 斜後外方に走行し, 膀胱(ガバ) 経と平行に走行し，上天柱穴付近に終る。

頭頂葉(神経伝達物質ドバミン)は前頂穴付近よ り始まり, 斜後外方に走行し, 前頭葉(経)の内側 を走行し, 上天柱穴付近に終る。

前頭部より頭頂部までの○印はブロードマン大 脳皮質 10 野，9野，8野，6野を示す(図2)。

中脳(神経伝達物質ドバミン)は強間穴付近より 始まり斜後外方へ走行し, 膀胱経を横切って風地 穴付近に終る。

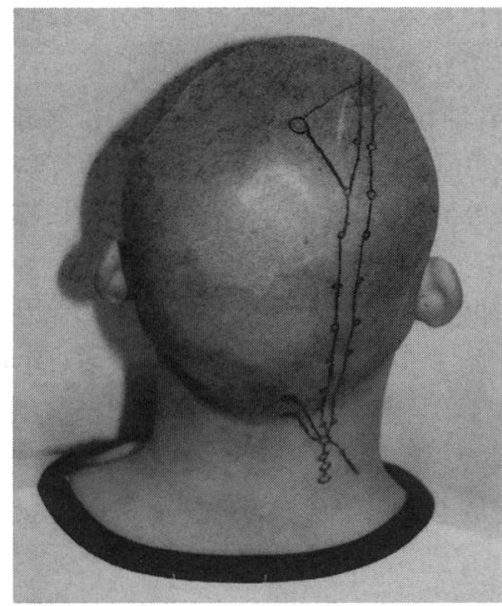

図 1 百会穴, 膀胱 (ガバ)経(内側), 膀胱 (セ ロトニン)経(外側)を示す

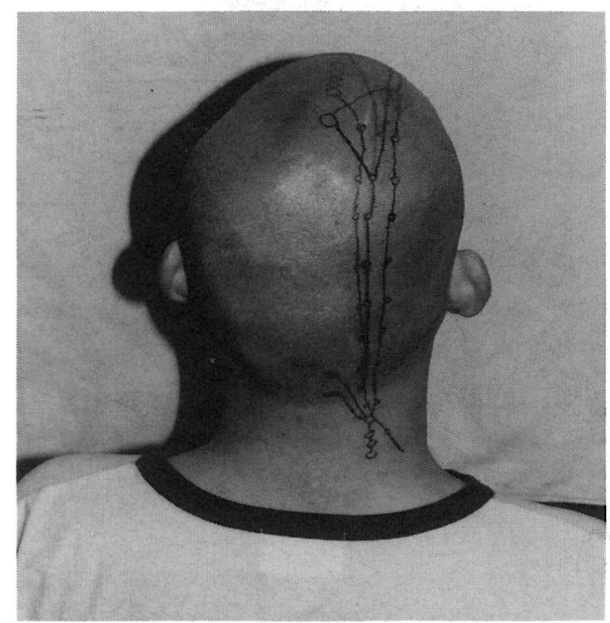

図2 前頭葉, 頭頂葉, 百会穴(中心灰白質), 膀胱(ガバ)経, 膀胱(セロトニン)経を示す 前頭葉より頭頂葉までの○はブロードマン 大脳皮質10野，9野，8野，6 野を示す

後頭葉(神経伝達物質セロトニン)は強間穴と脳 戸穴の中間付近より始まり斜後外方へ走行し膀胱 経を横切って風地穴付近に終る。

橋(神経伝達物質ドバミン)は脳戸穴付近より始 まり後頭葉と同じように風地穴付近に終る。

延䯣(神経伝達物質ノルアドレナリン)は外後頭 隆起のすぐ下より始まり，後頭葉と同じように風 
地穴付近に終る。この経穴は上半分が延髄に反応

し，下半分が海馬に反応する。

側頭葉(神経伝達物質セロトニン)は懸覻穴付近 より始まり側頭部を走行し完骨穴付近で終る(図3)。 症例により膀胱(セロトニン)経に合する症例もあ る。

小脳(神経伝達物質ガバ)は督脈上の第 2 頸椎の 高さより始まり第 4 頸椎の高さで終る(図 4 )。

症例により上天柱穴付近に終るのが，風地穴に 終る症例や，風地穴付近で終るものが上天柱付近 で終る症例もある。

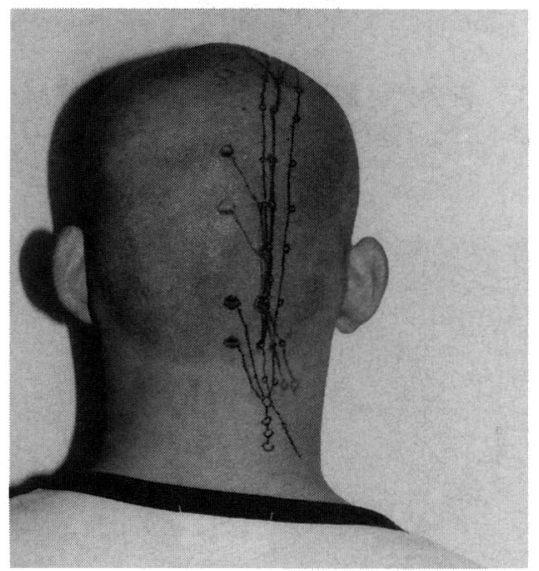

図3 中脳, 後頭葉, 橋, 延髄, 側頭葉を示 す。百会穴より後方の○は大脳ブロードマ ン 7 野, 19野を示す

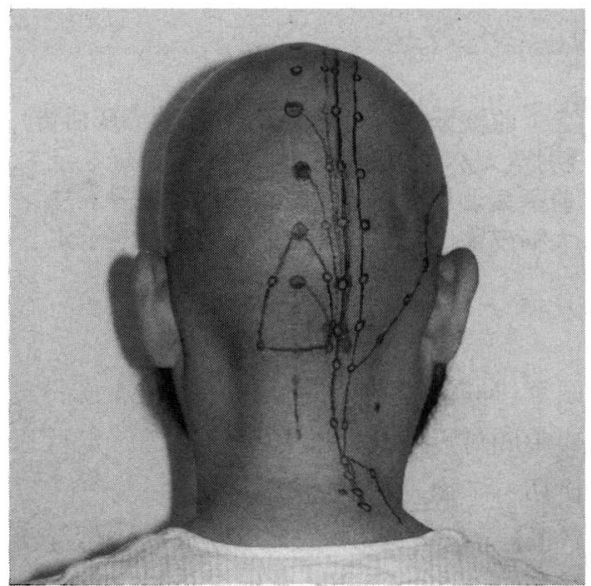

図4 中脳, 後頭葉, 橋, 延髄, 小脳, 側頭 葉が膀胱(セロトニン)との合流を示す

\section{$\mathrm{V}$ 考察}

大脳白質の神経線維 ${ }^{4)}$ は，1）投射線維，2）連 合線維，3）交連線維の 3 種があり，投射線維は 大脳皮質から出て内包へ行っている線維で，皮質 核路，皮質脊髄路，皮質橋路，視床，線状体，網 様体, 黑質, 視床下核, 四丘体, 赤核へ向う線維 である。

連合線維は大脳白質の主たる構成要素である。 この線維は近くの脳回や遠く離れている皮質部分 をお互い結びつけている。

交連線維は脳梁や，前交連を介して左右の大脳 半球をお互い連絡している。このことより，我々 神経伝達物質を使用するO.R.T法で描写した前頭 葉，頭頂葉……等はこの投射線維か連合線維を描 写しているのではないかと考えられる。

しかし期門穴より百会穴に流注する肝経の支脈 を描写するにはブロードマン大脳皮質17野と神経 伝達物質アドレナリン ${ }^{1}$ を使用すると, 支脈が後頸 部より百会穴に流注する(図 5 )が, 神経伝達物質 セロトニンを使用すると後頭部に描写出来る。

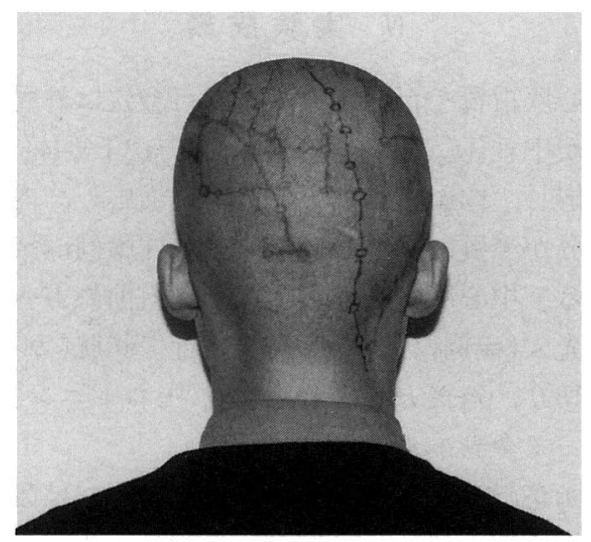

図 5 肝経の支脈が後頸部より百会穴に入る を示す

ブロードマン大脳皮質野で大脳の内側にあるも の(11野，10野，9野…)は督脈上より始まり，上 天柱穴付近がまたは風地穴付近に終っている。側 頭葉(21野)は懸覻穴付近より始まり完骨穴付近に 終っている。症例により上天柱付近に終る症例も ある。 
このことより，中枢神経に関する疾患の治療に 頭頸部の督脈上の経穴, 上天柱穴, 天柱穴, 風地 穴は有効な経穴であると示唆された。

\section{VI 結 語}

我々は神経伝達物質を使用するO.R.T法で主な 脳の各組織を使用してイメージングを行い，頭部 より後頸部にかけての神経線維を描写した。

\section{参考文献}

1）重松俊朗ほか：Bi-Digital O-Ring Test (O.R.T) による経絡，経穴のイメージについて，第一報 神経伝達物質を使用した経絡, 経穴のイメージ ングの方法について，全日本銊炎学会誌 40 ; 315 318. (1990)

2）重松俊朗, 田山文隆：Bi-Digital O-Ring Test (O.R.T)による経絡, 経穴のイメージングについ て，第二報自律神経中枢(視床) と経絡, 経穴の 関係について，全日本鍼炎学会誌 40;402～404。 (1990)

3）重松俊朗, 田山文隆：Bi-Digital O-Ring Test (O.R.T)による経絡, 経穴のイメージングについ て，第三報各経絡と大脳皮質の関係について， 全日本銊炎学会誌 40;405 407. (1990)

4) Peters Diws : 神経局在診断一その解剖生理, 臨 床一，株式会社 文光堂，(1989), p.316 321. ( $=830$ 久留米市西町花畑956 重松俊朗) 


\title{
A Study on Imaging of Meridians and Acupoints by Means of the Bi-Digital O-Ring Test
}

\author{
The 6th Report \\ _ Imaging of the Brain by Regions __ \\ Shunro Shigematsu and Fumitaka Tayama \\ Chikugo Oriental Medicine Association
}

Imaging of the brain was carried by means of the bi-digital-O-ring test (ORT) with tissue in each region using neurotransmitters.

Frontal lobe (Brodmann's area 11) starts around Hsinhui, runs oblique-extero-posteriorly in parallel to the bladder (GABA) meridian and arrives at or around the area above Tienchu.

Parietal lobe (Brodmann's area 4) starts from around Chienting, runs oblique-extero-posteriorly through the inner side of the frontal lobe (meridian) and arrives at or around the area above Tienchu.

Central gray indicates Paihui. Central gray runs from Paihui oblique-extero-anteriorly, intersects the bladder (GABA) meridian around Chengkuang (Tungtien in some cases), runs further oblique-extero-posteriorly, intersects the bladder meridian (serotonin), and runs all over the body.

Mesencephalon (tissue excised along the line including red nucleus) starts from around Chiangchien, runs oblique-entero-posteriorly, intersects the bladder meridian and arrives at or around Fengchin.

Occipital lobe (Brodmann's area 17) starts from the intermediate of Chiangchien and Naohu, ruus oblique-extero-posterioly, intersects the bladder meridian, and arrives at or around Fengchin.

Pons (tissue excised along the line including nucleus ceruleus) starts from around Naohu, and arrives at Fengchin in the same manner as noted with the occipital lobe.

Medulla (tissue excised along the line including inferior Olivary nucleus at the swollen part) starts from immediately below external occipital protuberance, and arrives at or around Fengchin in the same manner as noted with the occipital lobe. The upper half of this meridian point reacts with medulla, while the lower half of the same reacts with hippocampus.

Temporal lobe (Brodmann's area 21) starts from around Hsuanlu, runs through the temple, and arrives at or around Wanku, or in some cases joins to the bladder (serotonin).

Cerebellum (tissue excised along the line including dentate nucleus) starts from the Governor vessel medidian at a level of the second cerebral vertebra, and arrives at the level of the 4th cervical vertebra.

From the above it was suggested that meridians on the Governor vessel of the cephalocervical region, the meridian above Tienchu, Tienchu, and Fengchin are useful for treatment of diseases related to the central nerve system. 